\title{
Skistosomose, 'n onderskatte en verwaarloosde probleem, selfs in die endemiese gebiede van die Republiek van Suid-Afrika
}

\author{
C.T. Wolmarans en K.N. de Kock \\ Skool vir Omgewingswetenskappe en -ontwikkeling, Potchefstroomse Universiteit vir Christelike Hoër Onderwys, \\ Potchefstroom 2520
}

Ontvang 6 Augustas 1998; aanvaar Mei 2000

\section{UITTREKSEL}

Na raming het hussen drie en vier miljoen mense in die endemiese gebiede van die RSA skistosomose onder lede. Hierdie raming is hoofsaaklik op die prevalensie van skistosomose soos dit by skoolgaande kinders gevind is, gebaseer: Die huidige ondersoek wat hoofsaaklik van buitepasiënte-rekords, wat tussen 1990 en 1995 by die Letaba Hospitaal versamel is, gebruik gemaak het, het ten doel gehad om die getal skistosoom-positiewe gevalle wat tydens hierdie periode by die hospitaal geidentifiseer is, vas te stel. Die mate wartoe hierdie prevalensie 'n realistiese beeld van die waarskynlike getal positiewe gevalle wat normaalweg by die hospitaal rapporteer; verteenwoordig, is ook ondersoek. Aandag is verder geskenk aan die voorkoms van hematurie soos dit deur die buitepasiënte-rekords gereflekteer word en of dit enige sinvolle assosiasie met die skistosoom-positiewe gevalle getoon het.

\begin{abstract}
Schistosomiasis, an underestimated and neglected problem, even in the endemic areas of the RSA

It is estimated that between three and four million people in the RSA are infected with parasites that cause human schistosomiasis. These estimates are based mainly on the incidence of schistosomiasis in school children in the schistosomiasis endemic areas of the country. The aim of the current investigation, which made use mainly of outpatient records compiled between 1990 and 1995 at the Letaba Hospital, was to establish the number of schistosomiasis positive cases identified during this period. The extent to which the incidence of this condition reflected a realistic image of the probable number of positive cases in patients normally attending the hospital was also investigated. Attention was also paid to the occurrence of haematuria as reflected by the outpatient records, and an attempt was made to determine whether this showed any meaningful relationship with the schistosomiasis positive cases.
\end{abstract}

\section{INLEIDING}

Skistosomose, ook bekend as bilharziase, is 'n parasitiese sickte wat by mense voorkom en word in Suid- $\Lambda$ frika veroorsaak deur twee wurmparasietspesies wat behoort tot die genus Schistosoma. S. haematobium en $S$. mansoni, wat onderskeidelik verantwoordelik is vir urinêre en ingewandsbilharziase, is beide teenwoordig in die Noordelike Provinsic, Mpumalanga en Kwazulu-Natal wat ook die bilharziase-endemiese gebiede in SuidAfrika verteenwoordig.

Hierdie gebiede word oorwegend deur 'n tropiese-subtropiese klimaat gekenmerk met talle natuurlike waterhabitats en groot informele bchuisingsgebiede waar etlike miljoene mense woon. Formele behuising voorsien van water en sanitasie, is skaars, wat daartoc aanleiding gee dat die meeste van die inwoners in dić gebiede van natuurlike water vir bykans al hulle behoeftes afhanklik is. In sommige gebiede is daar boorgate en gemeenskaplike krane wat water hoofsaaklik vir drink- en kookdocleindes beskikbaar stel. Ontlasting en urinering in die veld en dikwels naby, of selfs in die water, is algemene praktyk en skep 'n ideale leefwyse vir die instandhouding van dic bilharziase-siklus wanneer die parasict eers in die water teenwoordig is.

Uit die literatuur is dit duidelik dat, afgesien van ander simptome, hematuric en proteïnuric oor dic algemeen as kliniese manifestasics van $S$. haematobium-infeksies aanvaar word. ${ }^{1-3}$ Hierdie kliniese verskynsels word deur parasieteiers veroorsaak wat uit bloedvate, teenwoordig in die blaaswand, na die lumen van die blaas migreer en mikroletsels in die blaaswand tot gevolg het. ${ }^{4-5}$ Dic gebruik van hematurie as diagnostiese hulpmiddel om skistosoominfeksies aan te dui, is veral onomwonde by kinders aangetoon. . $^{1,5,67}$ Ten spyte hiervan word dic gebruik van hematuric as indirekte diagnostiese hulpmiddel in die identifisering van skistosoombesmette mense vir grootskaalse morbiditeitsbeheerprogramme aanbeveel. Verskeic metodes om die teenwoordigheid van hematurie aan te toon, bestaan. Dit kan onder andere gedoen word by wyse van 'n vraclys, of deur visuele hematurie makroskopies vas te stel, of by wyse van reagensstrokies. Dic teenwoordigheid van die parasiet kan egter ook direk parasitologies vasgestel word, in welke geval die urine vir die teenwoordigheid van skistosoomeiers ondersoek word. Ten spyte daarvan dat al hierdie metodes enkele tekortkominge het en akkurate waardes van prevalensie nie van groter waarde as berekende waardes in die beheer van die siekte is nie, kan die waardes wat verkry word met metodes om hematurie vas te stel, bruikbaar wees in die beplanning en evaluering van beheermaatrëls. ${ }^{8}$ Volgens Mott et al. ${ }^{4}$ behoort hierdie en ander indirekte metodes in elke endemiese land geëvalueer te word en kriteriums vir interpretering vasgestel te word.

Die huidige ondersock, wat hoofsaaklik gebaseer is op inligting wat tussen 1990 en 1995 in hospitaalrekords opgeneem is, is uitgevoer om 'n idec te probecr vorm van die voorkoms van skistosomose onder buitepasiënte by 'n hospitaal in 'n bilharzia-endemiese gebied in die Noordelike Provinsie. Aandag is 
ook gegee aan die voorkoms van hematuric by hierdie hospitalal en die moontlike verband wat dit met skistosomose mag toon. Hieruit sou dit moonlik wees om te bepaal of hematurie oor diagnostiese potensiaal vir skistosomose in die gebied sou kon beskik. Tydens die ondersoekperiode was daar 'n drastiese afname in die jaarlikse reënval in die gebied en het daar ook veranderinge ten opsigte van die beskikbare mediese fasiliteite en die beleid van mediese sorg voorgekom. Dic feit dat skistosomose as 'n hoogs verwaarloosde sickte in dic RSA beskou word, ${ }^{10}$ het verder as motivering vir hierdie studie gedien.

\section{MATERIAAL EN METODES}

Die Letaba Hospitaal is in die Nkowankowa-vallei in die Letsitelegebied geleë. Dié vallei word deur ongevecr 75000 mense bewoon, waarvan talle immigrante uit Mosambick is wat as trekarbeiders op nabygeleë plase werk. Die grootste gedeclte van dić mense mak van informele bchuising gebruik wat nic van water of sanitêre geriewe voorsien is nie en grootliks van natuurlike water vir hulle daaglikse behoeftes afhanklik is. Persoonlike reiniging en die was van wasgoed vind hoofsaaklik in riviere en damme plaas, terwyl water vir drink- en kookdoeleindes by gemeenskaplike krane of boorgate verkry word, indien dit beskikbaar is. Die hospital word jaarliks deur ongeveer 55000 pasiënte besock. Pasiënte met een of ander meetbare graad van hematurie, of wat volgens die geneesheer moontlik ander bilharziase-verwante simptome vertoon, is vir hierdic studic gesclekteer. 6625 sodanige gevalle is tussen 1990 en 1995 geïdentifiseer, waarvan 2339 mans- en 4286 vrouepasiente was. Ouderdomsbepalings was riskant omdat talle van dic ooglopend bejaarde pasiënte, óf totaal ongeletterd was, ó geen identiteitsdokumente beskikbaar gehad het nic. Sommige pasiënte was onwillig om enige persoonlike besonderhede te verskaf, vermoedelik onwettige immigrante wat op dic nabygelcë plase werksaam was.

\section{URIENANALISE}

Urienmonsters is tussen 09:00 en 15:00 by dic geselekteerde persone in wyenek-flesse met skroefdeksels versamel, waarna dit in die laboratorium volgens die sedimentasietegnick soos beskryf deur McCullough en Magendant $z^{6}$ vir mikroskoopanalises voorberei is. Kortliks het dit behels dat 'n $10 \mathrm{ml}$ urien- monster wat deeglik geskud is, na 'n proelbuis oorgedra is en vir $5 \mathrm{~min}$. by 5000 o.p.m. gesentrifugeer is. Die sediment is vervolgens na 'n mikroskoopplatatjic oorgedra en met 'n dekglasic bedek. Die monsters is vervolgens by 'n $40 \mathrm{X}$-vergroting vir $S$. haematobium-eiers en 'n l60X-vergroting vir die tecnwoordigheid van rooibloedselle (RBS) ondersock. Dric mikroskoopvelde is vir elke monster ondersock. Dic aan- of afwesigheid van eiers is genoteer terwyl die gemiddelde graad van hematuric as + (1-10 RBS per mikroskoopveld), ++ (11-100 RBS per mikroskoopveld) en $+++(<100$ RBS per mikroskoopveld) aangedui is. Hicrdic kategorieë het respekticwelik ooreengestem met mikrohematuric (trocbel-geel), matige hematurie (trocbel-bruin) en erge hematuric (blocdrooi urine).

\section{RESULTATE}

Die resultate van dic voorkoms van hematurie by die mans en dic vroue word respektiewelik in tabelle 1 en 2 weergegee. Dic getal pasiënte wat met 'n spesificke graad van hematuric (+, ++ , of +++ ) en met of sonder die teenwoordigheid van ova gediagnoseer is, is as 'n persentasic van die totale getal hematuriegevalle per maand uitgedruk, waarna 'n gemiddelde waarde per jaar bereken is. Die betekenisvolheid van die verskille tussen die verskillende grade van hematurie, met of sonder die teenwoordigheid van skistosoom-ova, is aangetoon deur van ' $n$ tweerigting- $\Lambda$ nova-toets, gevolg deur 'n meervoudige vergelyking volgens dic Tukey-HSD-tocts, gebruik te maak. Uit tabel I wat dic gemiddelde persentasic van mans wat met hematurie en met, of sonder ova gediagnosecr is, voorstel, is dit duidelik dat dic manspasiënte wat +++-bloed en ova in die urine getoon het, vir al die jare behalwe 1995, betekenisvol van al die ander gevalle van hematurie, met of sonder ova, verskil het. In 1995 was daar geen betekenisvolle verskille tussen die +++-graad van hematurie met ova en die +-, ++-, of +++-graad van hematuric sonder ova, gevind nic. 'n Soortgelyke analise van dic vrouepasiënte (tabel 2) het aangetoon dat dic +++-graad van hematuric met ova slegs in 1991 en 1992 betekenisvol van al die ander grade van hematuric, met of sonder die teenwoordigheid van ova, verskil het. Dit is verder duidelik dat 'n gemiddeld van $43,5 \%$ van die manspersone wat oor die ses jaar by die hospital met skistosomose gediagnoseer is ' $n+++$-graad van hematurie

Tabel 1 Die gemiddelde persentasie manlike pasiënte wat jaarliks tussen 1990 en 1995 met hematurie gediagnoseer is met of sonder $S$. haematobium-ova in die urine

\begin{tabular}{|l|c|c|c|c|c|c|}
\hline \multicolumn{7}{|c|}{ Graad van hematuric } \\
\hline Jaar & \multicolumn{3}{|c|}{ Ova tecnwoordig } & \multicolumn{3}{c|}{ Ova afwesig } \\
\hline 1990 & + & ++ & +++ & + & + & ++ \\
\hline 1991 & $11,4 \pm 6,4^{*}$ & $11,9 \pm 7,8^{*}$ & $44,7 \pm 17,8$ & $11,9 \pm 6,0^{*}$ & $7,4 \pm 6,0^{*}$ & $12,45 \pm 15,9^{*}$ \\
\hline 1992 & $4,3 \pm 2,8^{*}$ & $13,2 \pm 6,1^{*}$ & $51,3 \pm 9,6$ & $11,2 \pm 6,0^{*}$ & $10,6 \pm 5,7^{*}$ & $9,8 \pm 6,6^{*}$ \\
\hline 1993 & $3,3 \pm 1,7^{*}$ & $12,0 \pm 7,6^{*}$ & $50,3 \pm 13,0$ & $12,1 \pm 4,7^{*}$ & $4,9 \pm 3,1^{*}$ & $17,0 \pm 7,1^{*}$ \\
\hline 1994 & $8,0 \pm 5,7^{*}$ & $10,6 \pm 4,9^{*}$ & $39,9 \pm 12,7$ & $16 \pm 7^{*}$ & $5,6 \pm 5,7^{*}$ & $13,6 \pm 8,1^{*}$ \\
\hline 1995 & $3,8 \pm 4,3^{*}$ & $4,9 \pm 5,5^{*}$ & $46,4 \pm 18,2$ & $17,2 \pm 18,2^{*}$ & $4,0 \pm 4,9^{*}$ & $21,6 \pm 13,5^{*}$ \\
\hline $\begin{array}{l}\text { Gemiddeld van } \\
\text { totale periode }\end{array}$ & $6,2 \pm 5,7^{*}$ & $2,4 \pm 3,2^{*}$ & $28,4 \pm 8,3$ & $26,4 \pm 18,2$ & $15 \pm 6$ & $21,8 \pm 15,5$ \\
\hline
\end{tabular}

* Dui op 'n betekenisvolle verskil tussen +++-graad van hematurie met ova teenwoordig in die urine en al die oorblywende grade vir hematuric. 
getoon het, terwyl dit in die geval van die vrouepasiënte $31,4 \%$ was. In laasgenoende geval het dit nie veel verskil van die $26,7 \%$ vroue wat nie skistosomose gehad het nie, maar ook 'n +t+graad van hematurie getoon het.

Die totale jaarlikse voorkoms van die verskillende grade van hematuric, met of sonder die teenwoordigheid van ova, word vir die mans in tabel 3 en vir die vroue in tabel 4 weergegee. Dit is uit die tabelle duidelik dat daar vanaf 1900 na 1995 by dic mans- en vrouepasiente 'n afname in dic totale getal hematuricgevalle was. Alhoewel hierdie afname by sowel die besmette as die onbesmette pasiënte voorgekom het, was dit in die geval van die besmette pasiente baic meer drasties en het dit gepaardgegaan met netto afnames by al die grade van hematurie afsonderlik. Dit is egter opvallend dat wanneer die afsonderlike grade van hematurie per jaar gevind, as 'n persentasie van die totale getal hematuriegevalle vir dieselfde jaar, uitgedruk word, (syfers tussen hakies) die voorkoms van elk van hierdic grade van hematurie tydens die periode van die ondersock min of meer konstant gebly het. Uit hierdie resultate is dit dus duidelik dat die afname in die totale getal hematuriegevalle tydens die ondersockperiode nie aan 'n afname in die voorkoms van een spesificke graad van hematuric alleen toegeskryf kan word nic.

Tabel 2 Die gemiddelde persentasie vroulike pasiënte wat jaarliks tussen 1990 en 1995 met hematurie gediagnoseer is met of sonder $S$. haematobium-ova in die urine

\begin{tabular}{|l|c|c|c|c|c|c|}
\hline & \multicolumn{3}{|c|}{ Graad van hematuric } \\
\hline Jaar & + & ++ & +++ & + & ++ & +++ \\
\hline 1990 & $7,3 \pm 4,9^{*}$ & $8,2 \pm 5,1^{*}$ & $28 \pm 13$ & $13,1 \pm 4,6^{*}$ & $13,0 \pm 8,4^{*}$ & $30,3 \pm 12,9$ \\
\hline 1991 & $4,6 \pm 2,2^{*}$ & $5,7 \pm 4,9^{*}$ & $38,8 \pm 9,4$ & $11,6 \pm 5,1^{*}$ & $7,9 \pm 3,7^{*}$ & $30,4 \pm 10,4$ \\
\hline 1992 & $7,7 \pm 4,8^{*}$ & $12,6 \pm 4,6^{*}$ & $41,3 \pm 7,9$ & $13,7 \pm 8,0^{*}$ & $6,0 \pm 4,9^{*}$ & $18,4 \pm 8,7^{*}$ \\
\hline 1993 & $5,6 \pm 5,4^{*}$ & $7,0 \pm 4,4^{*}$ & $26,6 \pm 14,2$ & $14,1 \pm 11,9$ & $10,7 \pm 9,1^{*}$ & $36,5 \pm 18,1$ \\
\hline 1994 & $8,3 \pm 6,5^{*}$ & $2,3 \pm 3,3^{*}$ & $33,1 \pm 15,5$ & $24,0 \pm 13,3$ & $10,1 \pm 9,8^{*}$ & $22,2 \pm 17,4$ \\
\hline 1995 & $8,1 \pm 7,2$ & $10,3 \pm 15,6^{*}$ & $20,6 \pm 13,7$ & $26,5 \pm 8,8$ & $11,7 \pm 7,0$ & $22,5 \pm 18,3$ \\
\hline $\begin{array}{l}\text { Gemid. van } \\
\text { totale periode }\end{array}$ & $6,9 \pm 5,1$ & $7,6 \pm 6,3$ & $31,4 \pm 12,2$ & $17,1 \pm 8,6$ & $9,9 \pm 7,1$ & $26,7 \pm 14,3$ \\
\hline
\end{tabular}

* Dui op 'n betekenisvolle verskil tussen +++-graad van hematurie met ova teenwoordig in dic urine en al die oorblywende grade vir hematuric.

Tabel 3 Die jaarlikse voorkoms van die verskillende grade van hematurie by mans wat met of sonder skistosoominfeksies gediagnoseer is. Elke graad van hematurie afsonderlik is ook as 'n persentasie van die totale getal hematuriegevalle vir 'n bepaalde jaar uitgedruk (syfers tussen hakies)

\begin{tabular}{|l|l|l|l|l|l|l|}
\hline $\begin{array}{l}\text { Graad van hematurie met } \\
\text { skistosoominfeksie }\end{array}$ & 1990 & 1991 & 1992 & 1993 & 1994 & 1995 \\
\hline Gecn & 2 & 3 & 5 & 12 & 7 & 3 \\
\hline+ & $74(15)$ & $31(6,5)$ & $18(5,1)$ & $33(12)$ & $14(9,5)$ & $15(18)$ \\
\hline++ & $83(18)$ & $87(18)$ & $66(18)$ & $49(18)$ & $19(12)$ & $8(9)$ \\
\hline+++ & $301(65)$ & $355(75)$ & $266(76)$ & $177(68)$ & $114(77)$ & $59(71)$ \\
\hline $\begin{array}{l}\text { Totale getal } \\
\text { hematuriegevalle }\end{array}$ & 458 & 473 & 350 & 259 & 147 & 82 \\
\hline $\begin{array}{l}\text { Graad van hematuric } \\
\text { sonder skistosoominfeksie }\end{array}$ & 1990 & 1991 & 1992 & 1993 & 1994 & 1995 \\
\hline Geen & 4 & 26 & 8 & 6 & 12 & 7 \\
\hline+ & $69(42)$ & $78(36)$ & $68(35)$ & $73(46)$ & $47(41)$ & $51(39)$ \\
\hline++ & $37(22)$ & $66(30)$ & $29(15)$ & $26(16)$ & $11(9)$ & $20(15)$ \\
\hline+++ & $53(32)$ & $69(32)$ & $92(48)$ & $57(36)$ & $55(48)$ & $57(44)$ \\
\hline $\begin{array}{l}\text { Totale getal } \\
\text { hematuriegevalle }\end{array}$ & 163 & 213 & 189 & 156 & 113 & 128 \\
\hline
\end{tabular}


Uit tabelle 3 en 4 is dit duidelik dat skistosomose, feitlik sonder uitsondering, altyd met hematuric gepaardgegaan het. Dic drastiese afname in die hoeveclheid hematuriegevalle tydens dic ondersockteperiode, verteenwoordig dus ook 'n afname in dic totale voorkoms van skistosomose soos dit by die hospital gediagnosecr is.

Gegewens aangaande die getal pasiënte wat dic hospitaal per jaar tydens hicrdic periode besock het, die getal mikrokopiese urienanalises wat per jaar uitgevoer is, die getal skistosoomgevalle wat hieruit geïdentifiseer is en die totale jaarlikse reënval tydens die periode word in tabel 5 weergegee. Hieruit is dit duidelik dat die getal pasiënte wat die hospitaal tussen $1990 \mathrm{en}$ 1995 besock het, min of meer konstant gebly het, terwyl daar 'n drastiese afname in die getal urienanalises wat uitgevoer is, voorgckom het. In 1990 het $9,24 \%$ van dic pasiënte wat dic hospitaal besock het urienanalises ondergaan, terwyl dit in 1995 slegs $2,73 \%$ was. Hierdic omstandighede sou noodwendig daartoc aanleiding kon gee dat daar ook ' $n$ afname in dic getal gediagnosecrde skistosoomgevalle behoort te gewees het, 'n aanname wat duidelik in die tabel geïllustrecr word deurdat daar in 1990, 1172 gevalle van skistosomose was, terwyl daar in 1995 slegs 290 gevalle was. Wanneer die getal skistosoomgevalle per jaar gevind, egter as 'n persentasic van die totale getal urienanalises vir dieselfde jaar uitgedruk word, is dit duidelik dat dit tydens die periode van ondersock min of meer konstant gebly het, dit ten spyte van die bevinding dat daar tussen $1990 \mathrm{cn}$ 1994 'n aansienlike afname in die totale jaarlikse reënval in die gebied was. Hierdie bevinding bevestig dat korttermynafnames in reënval weinig invloed op dic prevalensic van die sickte in 'n gebied behoort te hê, veral gesien in die lig van dic feit dat $S$. haematobium-wurms gemiddeld 5-15 jaar in mense oorleef en ova produseer. Die aanvanklike afleiding dat daar 'n afname in

Tabel 4 Die jaarlikse voorkoms van die verskillende grade van hematurie by vroue wat met of sonder skistosoominfeksies gediagnoseer is. Elke graad van hematurie afsonderlik is ook as 'n persentasie van die totale getal hematuriegevalle vir ' $n$ bepaalde jaar uitgedruk (syfers tussen hakies)

\begin{tabular}{|l|l|l|l|l|l|l|}
\hline $\begin{array}{l}\text { Graad van hematurie } \\
\text { met skistosoominfeksie }\end{array}$ & $\mathbf{1 9 9 0}$ & 1991 & 1992 & 1993 & 1994 & 1995 \\
\hline Gecn & 3 & 8 & 6 & 4 & 9 & 11 \\
\hline+ & $98(17)$ & $48(9)$ & $43(12)$ & $22(13)$ & $13(19)$ & $32(19)$ \\
\hline++ & $113(19)$ & $60(11)$ & $71(20)$ & $26(15)$ & $9(5)$ & $29(19)$ \\
\hline+++ & $360(63)$ & $393(78)$ & $232(67)$ & $115(76)$ & $118(74)$ & $86(58)$ \\
\hline $\begin{array}{l}\text { Totale getal } \\
\text { hematuriegevalle }\end{array}$ & 571 & 501 & 346 & 163 & 158 & 147 \\
\hline $\begin{array}{l}\text { Graad van hematurie } \\
\text { sonder skistosoominfeksie }\end{array}$ & 1990 & 1991 & 1992 & 1993 & 1994 & 1995 \\
\hline $\begin{array}{l}\text { Gecn } \\
+\end{array}$ & 23 & 31 & 13 & 9 & 16 & 14 \\
\hline++ & $157(24)$ & $116(23)$ & $84(37)$ & $55(25)$ & $94(46)$ & $101(45)$ \\
\hline+++ & $148(22)$ & $77(15)$ & $38(16)$ & $40(18)$ & $37(18)$ & $38(17)$ \\
\hline $\begin{array}{l}\text { Totale getal } \\
\text { hematuriegevalle }\end{array}$ & $340(52)$ & $296(60)$ & $103(45)$ & $122(56)$ & $71(35)$ & $83(37)$ \\
\hline
\end{tabular}

Tabel 5 Die totale getal hospitaalbesoeke, urienanalises en skistosoom-positiewe gevalle per jaar aangeteken vir die 1990 - 1995-periode sowel as die totale jaarlikse reënval vir dieselfde periode

\begin{tabular}{|l|c|c|c|c|c|c|c|}
\hline Jaar & $\begin{array}{c}\text { Jaarlikse getal } \\
\text { buitepasiënte }\end{array}$ & $\begin{array}{c}\text { Jaarlikse getal } \\
\text { mikroskopies } \\
\text { geanaliseerde } \\
\text { urienmonsters }\end{array}$ & $\begin{array}{c}\text { Jaarlikse getal } S . \\
\text { haematobium-positiewe } \\
\text { gevalle as \% van die } \\
\text { getal buitepasiënte } \\
\text { uitgedruk }\end{array}$ & $\begin{array}{c}\text { Die \% } \\
\text { S. hacmatobium- } \\
\text { positiewe gevalle / } \\
\text { urienanalises }\end{array}$ & $\begin{array}{c}\text { Die persentasie } \\
\text { urienanalises/ } \\
\text { jaarlikse } \\
\text { besoeke }\end{array}$ & $\begin{array}{c}\text { Die totale } \\
\text { jaarlikse } \\
\text { reënval }\end{array}$ \\
\hline 1990 & 50478 & 4664 & 1172 & 2,32 & 25,12 & 9,24 & 540 \\
\hline 1991 & 53662 & 4827 & 1199 & 2,23 & 24,84 & 8,99 & 383 \\
\hline 1992 & 45397 & 2602 & 817 & 1,79 & 31,39 & 5,73 & 251 \\
\hline 1993 & 47141 & 2836 & 753 & 1,59 & 26,55 & 6,02 & 231 \\
\hline 1994 & 43734 & 1350 & 398 & 0,91 & 29,48 & 3,09 & 198 \\
\hline 1995 & 48356 & 1321 & 290 & 0,06 & 22,95 & 2,73 & 408 \\
\hline
\end{tabular}


die getal skistosoomgevalle en die gepaardgaande voorkoms van hematurie tydens die periode van ondersoek voorgekom het, blyk dus fouticf te wees. Die direkte eweredigheid tussen die getal skistosoonpositiewe gevalle en die getal urienanalises kom in hicrdie studie duidelik na vore en dui daarop dat dit gewens is dat hierdie analises by meer pasiënte gedoen word ten einde 'n meer realistiese beeld van die voorkoms van skistosomose by hicrdic hospitaal te verkry.

Die resultate van 'n ter plaatse ondersock wat in 1995 uitgevoer is en waartydens urienmonsters van 100 pasiënte per seisoen op geselekteerde agtereenvolgende dae vir die tecnwoordigheid van skistosoom-ova ondersock is, het aan die lig gebring dat 'n gemiddeld van $11,72 \%$ van alle pasiënte ova in hulle urine getoon het. Dit verskil aansienlik van die maksimum van $2,32 \%$ van die positiewe gevalle wat in 1990 by die hospitaal gevind is toe slegs $9,24 \%$ van die pasiente urienanalises ondergaan het, en van die $0,06 \%$ wat in 1995 geïdentifiseer is toe slegs $2,7 \%$ van dic pasiënte urienanalises ondergaan het (tabel 5). Dic resultate van die laasgenoende ondersock bevestig dic aanbeveling dat meer urienanalises as wat selfs in 1990 uitgevoer is, gedoen behoort te word om ' $n$ realistiese beeld te kry van dic die voorkoms van skistosomose by mense wat die hospitaal met dic oog op bchandeling besock.

\section{BESPREKING}

Dic huidige ondersock wat by ' $n$ groot hospitaal in 'n skistosoom-endemiese gebied uitgevoer is, het ten docl gehad om, deur hoofsaaklik van buitepasiënte-rekords gebruik te maak, 'n idec te probeer vorm van die omvang van hicrdic probleem in 'n bepaalde endemiese gebied, asook om die bruikbaarheid van hicrdic rekords in die bepaling van beleidsraamwerke ten opsigte van die diagnose van skistosomose te evaluecr. Die gebruik van hematurie as indirekte diagnostiese hulpmiddel in die identifikasic van $S$. haematobium-infeksies is goed gevestig en verskeie studies is in dic verlede gedoen om hierdie verskynsel by veral skoolkinders ${ }^{11,12}$ en die gemeenskap in dic bre ${ }^{12.13}$ te ondersock. Hierdie studies en andere het getoon dat, veral in die geval van kinders, 'n hoë voorkoms van sigbare hematurie en ander kliniese manifestasies dic gevolg van $S$. haematobium-infeksies is $^{3}$ en dat urinêre skistosomose klinies as hematuric en proteinurie presenteer.

Alhoewel die resultate van die huidige ondersock op 'n enkele urienanalise per pasiënt gebaseer is, het Savioli et al. ${ }^{14}$ gevind dat 'n enkele urienfiltrasic voldoende is om mense korrek vir beide epidemiologiese studies en selektiewe populasicchemoterapie te klassifiseer. Daarbenewens was 'n enkele urienfiltrasie ook voldoende om 'n aanduiding te gee van dic prevalensic, sowel as dic intensiteit van besmetting. Daar moet egter in gedagte gehou word dat weens die daaglikse variasic in ovaekskresic, dit moontlik is dat alle skistosoom-positiewe gevalle met hematurie nie geïdentifiseer kon word nic.

In dic huidige ondersock is gevind dat slegs dic +++ -graad van hematurie met ova betekenisvol van al die ander grade van hematuric verskil het, ongeag of daar ova teenwoordig was of nic. Hicrdic verskil kon egter nic in 1995 aangetoon word nic. Soortgelyke verskille is nie in $1991 \mathrm{en} 1992$ by die vrouepasiente aangetoon nic. Dit wil dus voorkom of slegs dic +++-graad van hematuric by mans oor moontlike diagnostiese potensiaal beskik. Of ander faktore by dic vrouepasiënte wat vir hematuric verantwoordelik kan wees, soos bv. menstruasic, die resultate van die vrouc kon beïnvloed, is nie seker nic. Hierdic bevinding is tot 'n mate in teenstelling met wat in die literatuur gevind is, $\mathrm{nl}$. dat hematurie, ongeag dic graad daarvan, as diagnosties vir skistosoominfeksies beskou kan word. Amali's het aangetoon dat hematuric in $80 \%$ van die gevalle met skistosoombesmettings gepaardgegaan het en selfs in $90 \%$ van die gevalle waar meer as 50 ova per $10 \mathrm{ml}$ urine uitgeskei is. Die omstandigheid dat die tendens soos in die huidige studie gevind, nie in 1995 voorgekom het nic, kan eerder aan die gebrek aan genoegsame data as aan skistosomose-verwante verskynsels tocgeskryf word. Die drastiese afname in uricnanalises van 1172 in 1990 na 290 in 1995 ondersteun hierdie afleiding. Hierdic afname beïnvloed nie alleen dic evaluering van dic diagnostiese potensiaal van skistosomose-verwante patologiese verskysels nic, maar lei ook tot die ontstaan van 'n skewe beeld ten opsigte van die erns van dic problecm in endemiese gebiede. Dit word bevestig deur dic bevindinge in die huidige studic dat daar met 'n toename in dic getal urienanalises ook 'n betekenisvolle toename in die getal positief gediagnoseerde gevalle voorgekom het. Selfs die $11,72 \%$ positiewe gevalle wat in die huidige ondersoek gevind is, moet as 'n hoogs konserwatiewe waarde beskou word omdat slegs 4 $\%$ van dic urienmonsters wat ondersock is van persone jonger as 16 jaar afkomstig was. Ondersocke wat tans in die Mamitwanedersetting aan die gang is en vir wie se inwoners dic Letaba Hospitaal dic naaste is, het aan dic lig gebring dat $88 \%$ van dic kinders jonger as 14 jaar met $S$. haematobium besmet was en dat $83 \%$ van hulle een of ander vorm van hematurie getoon het. Die feit dat hierdie persentasie nie deur die hospitaalrekords gereflekteer word nie, dui enersyds op die moontlikheid dat kinders hematurie nie as 'n ernstige simptoom beskou nie en daarom nie mediese hulp sock nic, 'n afheiding wat deur dic literatuur ondersteun word ${ }^{10} \mathrm{en}$ andersyds dui dit op die gevaar om hospitaalrekords ten opsigte van skistosomose, as verteenwoordigend van dic situasic soos dit in dic omgewing daar uitsien, te beskou. Die gebrek aan 'n holistiese benadering ten opsigte van skistosoombestryding het in dic ondersock duidelik aan die lig gekom. Enersyds wil dit voorkom of besmette kinders wat hoofsaaklik vir dic transmissic van die parasiet verantwoordelik is, weens 'n gebrek aan inligting nic dic erns van dic problecm besef nic en dus nie mediese hulp soek nic, en andersyds dat hospitaalpersonecl, of nic genoegsaam daarop bedag is nic, of nic oor genoeg personecl beskik nie en daarom nic groot getalle urienanalises uitvoer nic. Dic rede vir die sterk afname in urienanalises tussen $1990 \mathrm{cn} 1995$ is onbekend Alhoewel daar verskeic gesondheidsentrums en klinieke in dic gebied opgerig is, is gevind dat urienondersocke steeds net by die hospitaal uitgevoer word. Die moontlikheid dat 'n afname in die buitepasiëntbesocke hiervoor verantwoordelik kon wees, word weerlê deur die bevinding dat 'n sodanige afname nie plaasgevind het nic. Dic aanstelling van buitelandse geneeshere, wat óf nic op hoogte van parasiticse sicktes soos skistosomose is nic, of kommunikasicprobleme met die plaaslike bevolking ervaar en daarom nie die positiewe gevalle genoegsaam identifiseer nie, kon ecrs, indien wel, na dic 1994 algemene verkiesing 'n invloed op die gegewens gehad het omdat hicrdic persone eers ná die verkiesing aangestel is.

\section{SUMMARY}

Schistosomiasis, also known as bilharziasis, is a parasitic discase affecting humans in South $\Lambda$ frica. It is caused by two worm parasite species of the genus Schistosoma. S. haematobium, responsible for urinary bilharziasis, and $S$.mansoni, which causes intestinal bilharziasis, are both present in the endemic areas in South $A$ frica. These areas fall mainly in the Northern Province, Mpumalanga and Kwazulu-Natal and are characterised by a tropical-subtropical climate, many natural water habitats and large informal settlements occupied by several million people. Since formal housing with proper water and sanitation is rare, most of the people are dependent on natural water for all their needs. Defeacation and urination in the veld is common prac- 
ticc, a way of life ideal for maintaining the bilharziasis cycle once it is introduced into a water habitat.

This investigation, based mainly on information obtained from outpatient records compiled between 1990 and 1995, was conducted to form an idea of the incidence of this disease as recorded at a hospital in an endemic area. Attention was also paid to the prevalence of hacmaturia among patients seen at this hospital and its association with schistosomiasis, which would make it possible to establish whether or not this phenomenon would be of any diagnostic value in the area concerned.

Urine specimens were collected and examined microscopically for the presence of $S$. haematobium ova and hacmaturia. The degree in which hacmaturia occurred was classified into three categories: + (1-10 red blood cells per 160x magnification) $+(11-100$ red blood cells per 160x magnification) and $+++(<100$ red blood cells per $160 x$ magnification). These respective categorics are comparable to micro hacmaturia (cloudy yellow urine), mild hacmaturia (cloudy, brown urinc) and gross hacmaturia (blood red urinc).

The results of this study indicated that only the +++ degrec of haematuria with ova, as found in males, differed significantly from all the other degrees of haematuria, regardless of whether or not ova were present. The fact that this difference could not be established in 1995 may be ascribed to a lack of sufficient data collected during 1995 rather than to schistosome-related phenomena - a conclusion based on the drastic decrease in urine analysis from 1172 in 1990 to 270 in 1995. Corresponding differences for females could only be demonstrated for 1991 and 1992. From this it is evident that the +++ degree of haematuria may have diagnostic potential only for males. It could not be established with certainty whether factors like menstruation could have influenced the results as found in females. The decrease in urine analyses influenced not only the diagnostic potential of both schistosome-related pathological phenomena, but also the perception of the seriousness of this discase in endemic arcas. This is supported by the fact that an increase in urine analysis led to a significant increase in positively diagnosed cases in the current investigation. The $11.72 \%$ positive cases found in the study conducted by the authors in 1995 should also be regarded as highly conservative as only $4 \%$ of the patients involved were under the age of 16 . Investigations currently in progress among the inhabitants of the Mamitwa Village, for whom the Letaba Hospital is the nearest medical facility, show that $88 \%$ of children under the age of 14 are infected, of which $83 \%$ passed blood in their urine. The fact that these pereentages are not reflected by hospital records may be ascribed to the phenomenon that children do not regard bloody urine as a scrious problem and therefore do not seck medical attention for it. It is further clear from this finding that hospital records per $s e$ are poor reflections of the status of schistosomiasis in the community. The lack of a holistic approach with regard to schistosome control was clearly defined by this investigation. It seems obvious that children, who could be regarded as the main factor in the transmission of schistosomiasis, fail to seck medical attention because they are unaware of the seriousness of the prob$\mathrm{lcm}$. It is also possible that hospital personnel are not aware of the problem and therefore do not pay nough attention to it, or that there is a shortage of personnel qualified to perform additional urine analyses. No obvious reason could be found for the drastic decrease in urine analyses. Although several new health centres and clinics have been erected in the area, urine analysis is still being done only at the Letaba Hospital. The possibility that a decrease in the number of outpatients could have caused this decrease in urine analyses can be overruled as the annual attendance remained more or less constant. The appointment of foreign doctors, who may cither not be aware of the schistosomiasis problem or may experience difficultics in communicating with patients, could have contributed to this situation, but only since 1994, when the practice of appointing foreign doctors was introduced.

\section{LITERATUURVERWYSINGS}

I. Sarda, R.K. Minjas, J.N., Mahikwano, L.F. (1986). Further observations on the usc of gross hacmaturia as an indirect screcning technique for the detection of Schistosoma haematobitm infection in schoolchildren in Dar es Salaam, Tamzania, J. Trop. Med. Iyg., 89, 309-312.

2. Kassim, O.O. (1989). Protcinuria and hacmaturia as predictors of schistosomiasis in children, Amn. Trop. Paed., 3, 156-160.

3. Ozumba, N.A., Christensen, N.O., Nwosu, A.B.C., Nwaorgu, O.C. (1989). Endemicity, focality and scasonality of transmission of human schistosomiasis in Amagunze Village, castcrn Nigeria, $J$. I/c/minth., 63, 206-212.

4. Wilkins, H.A., Goll, P., Marshall, T.F. de C., Moorc, P. (1979). The significance of protcinuria and hacmaturia in Schistosoma haematobium infection, Trans. Roy. Soc: Trop. Med. Myg., 73, 7480.

5. Dochring, E., Vester, U., Ehrich, J.H.H., Feldmcicr H. (1985). Circadian variation of ova excretion protcinuria, hacmaturia, and lcucocyturia in urinary schistosomiasis, Kilney linternat., 27, 667671 .

6. Mc Cullough, F.S., Magendantz, M. (1974). An epidemiological investigation into Schistosoma mansoni transmission in Mwanza, Tanzania, Ann. Trop. Med. Parasit., 68, 69-80.

7. Savioli, L., Hatz, C., Dixon, H., Kisumku, U.M., Moll, K.E. (1990). Control of morbidity duc to Schistosoma haematobium on Pemba Island; egg excretion and hacmaturia as indicators of infection, $A \mathrm{~m}$. J. Trop. Med. IJyg., 43, 289-292.

8. Eltoun, I.A., Sulaiman, S., Ismael, B.M., Ali, M.M.M., Elfatih, M., Homcida, M.H.A. (1992). Evaluation of hacmaturia as indirect screening test for Schistosomiasis haematobium: a population-based sludy in the White Hile Province, Sudan, Acta Tropica, 51, 151157.

9. Mott, K.E., Dixon, H., Osci-Tutu, E., England, E.C., Ekuc, K., Tcklc, A., 1985. Evaluation of reagent strips in urine tests for detection of Schistosoma haematobitum infection, a comparative study in Ghana and Zambia, Bull. Wld. H/lh. Org. 63, 125-133.

10. Schutte, C.H.J., Fripp, P.J., Evans, A.C., 1995. An assessment of the schistosomiasis situation in the republic of South Africa, South Afr. J. Epidemiol. Infect., 2, 37-43.

11. Sarda, R.K., Minjas, J.N., Mahikwano, L.Г. (1985). Evaluation of indirect screcning techniques for the detection of Schistosoma haematobium infection in an urban area, Dar es Salaam, Tanzania, Acta Tropica, 42, 24I- 247.

12. Nwaorgu, O.C., Anigbo, E.U. (1992). The diagnsotic value of hacmaturia and protcinuria in Schistosoma haematobium infection in southern Nigeria, J. Helminth., 66, 177-185

13. King C.H., Keating, C.E., Muruka, J.F., Ouma, J.H., Houscr, H., Arap Siongok, T.K., Mahmoud, A.A.F. (1988). Urinary tract morbidity in schistosomiasis hacmatobia; associations with agc and intensity of infection in an endemic area of Coast Province, Kenya, J. Trop. Med. Ilyg., 39, 361-368.

14. Savioli, L., Dixon, H., Kisumku, U.M., Mott, K.E. (1989). Control of morbidity due to Schistosoma haematobitm infection on Pemba Island: selective population chemotherapy of schoolchildren with hacmaturia to identify high-risk localitics, Trans. Roy. Soc. Trop. Med. Hyg., 89, 805-810.

15. Amali, O. (1994). Estimation of prevalences of urinary schistosomiasis using hacmaturia, Centr. Afr. J. Med., 40(6), 152-154. 